\title{
Dual crop coefficients and performance of evapotranspiration methods in irrigated wheat
}

\author{
Tonny José Araújo da Silva ${ }^{1}$, William Fenner ${ }^{2}$, Edna Maria Bonfim-Silva ${ }^{1}$, Thiago Franco Duarte ${ }^{1}$, Thiago \\ Henrique Ferreira Matos Castañon ${ }^{2}$, Luana Glaup Araújo Dourado², Maria Débora Loiola Bezerra²
}

\author{
${ }^{1}$ Federal University of Mato Grosso - UFMT, Institute of Agricultural and Technological Sciences - ICAT, 5055 Students \\ Avenue Rondonópolis, 78.735-901, Brazil \\ ${ }^{2}$ Federal University of Mato Grosso - UFMT, Faculty of Agronomy and Zootechnic - FAAZ, 2367, Fernando Corrêa da \\ Costa Avenue, 78060-900, Cuiabá, Brazil
}

\begin{abstract}
Water availability, fertilizer management and crop rotation are fundamental to the sustainability of agriculture and food security. Thus, the objective of this study was the determination of crops coefficients, verification and comparison of methods of estimation and determination of the evapotranspiration of irrigated wheat. The experiment was carried out during two consecutive years, in which BRS 254 varieties were cultivated in 2016 and BRS 394 in the year 2017. The evapotranspiration was estimated and determined using the dual kc methodology, FAO-56, with plants grown in 12 lysimeters filled with soil monoliths, and the loss of water by evaporation measured by weighing small-lysimeters. Evapotranspiration was also determined by the water balance method. The results measured in the lysimeters (standard method) were compared with the data simulated by the dual $k_{c}$ method and determined by method of soil water balance, in order to determine the accuracy and efficiency of the methods used. The coefficients used to determine the efficiency of the methods were the RMSE, the RSR and the confidence index "c". The total evapotranspiration of the crop in both years of cultivation was $360 \mathrm{~mm}$, with mean values of $3.87 \mathrm{~mm} \mathrm{~d}^{-1}$ for cultivar BRS 254 and $4.10 \mathrm{~mm} \mathrm{~d}^{-1}$ for cultivar BRS 394 . The basal crops coefficients in the emergence, tillering, flowering, maturation and harvest stages were $0.42,0.78,0.94,0.74$ and 0.47 for cultivar BRS 254 and $0.28,0.27,0.65,0.98$ and 0.66 for cultivar BRS 394. The soil water evaporation coefficients at the respective stages are 0.72 , $0.52,0.39,0.58$ and 0.13 for cultivar BRS 254 and 1.04, 0.96, 0.65, 0.34 and 0.51 for cultivar BRS 394. $K_{e}$ represents on average about $47 \%$ of the evapotranspiration of the irrigated wheat crop. Between methods tested, lysimeter is the best to wheat transpiration followed by FAO method and soil water balance. The use of any methods should consider the objectives and resources availability.
\end{abstract}

Keywords: Triticum aestivum L.; $\mathrm{k}_{\mathrm{c}}$ dual; water balance; soil-water dynamic water demand; instantaneous profile.

Introduction

Water is essential for plant growth and development, and it is fundamental to study the transfer processes in the soil-waterplant-atmosphere system. Scientific research has shown that evapotranspiration is related to the volumetric content of water in the soil and atmospheric demand (Doorenbos and Kassam, 1979; Allen et al., 1998), and several studies have been carried out with the objective of determining water consumption and optimizing water use in agriculture (Silva et al., 2005; Geerts and Raes, 2009; López-Urrea et al., 2009; ErRaki et al., 2010; Paredes et al., 2014; Silva et al., 2015; Wang et al., 2017).

The relationship between crop evapotranspiration and reference evapotranspiration results in the crop coefficient, called $k_{c}$, which is fundamental in studies related to evapotranspiration and irrigation system management (Allen et al., 2011a, 2011b; Paredes et al., 2014). However, its application is restricted because it provides a unique value for the loss of water by evaporation of the soil and by the transpiration of the plants. Thus, in scientific research it is recommended to use the dual coefficient of culture $k_{c}$, or double culture coefficient, which divides a single coefficient $\left(k_{c}\right)$ into two, $k_{c b}$ and $k_{e}$, basal growth coefficient and evaporation coefficient of water alone, respectively (Allen et al., 1998, 2005).

The determination of these coefficients in the field is not so simple, and water balance is often used in the soil by lysimetry to determine them. However, it is expensive equipment that does not always make its use feasible, making it necessary to use crop coefficients to estimate crop evapotranspiration.

In order to choose any method of estimating evapotranspiration or lysimetry, one should proceed carefully considering the variables and the available resources, since the methods and the models present local specificities as to the estimation efficiency. Considering this, the validation of the methods must be carried out to ensure the usefulness of the data and to minimize the errors in the estimation of evapotranspiration and irrigation management. 
The objective was the determination of crops coefficients, verification and comparison of methods of estimation (FAO) and determination (lysimeter and soil water balance) of the evapotranspiration of irrigated wheat cultivated in tropical climate.

\section{Results and discussion}

\section{Crop coefficients determined by lysimeters}

Table 2 shows the $k_{c b}, k_{e}, k_{c}, E T_{c}$ and $E T_{o}$ by wheat development stage (Large, 1954; Zadocks et al., 1974) irrigated in Cerrado of Mato Grosso State in the years 2016 and 2017 determined in weighing lysimeters.

The highest $k_{c b}$ values were 0.94 and 0.98 in the years 2016 and 2017, respectively, observed in the flowering and maturation of the crop. For the $k_{e}, 0.72$ and 1.04 were the values recorded between emergence and tillering of the crop in the years 2016 and 2017. The $k_{c}$ in turn presented a maximum value of 1.33 , which represents values above those recommended for the cultivation of wheat. $k_{e}$ represented from 22 to $78 \%$ of the $\mathrm{ET}_{\mathrm{c}}$ of the wheat crop, with an average value of $47 \%$ in both years of cultivation.

The mean values of $\mathrm{ET}_{\mathrm{c}}$ and $\mathrm{ET}_{\mathrm{o}}$ were $3.87,3.49 \mathrm{~mm} \mathrm{~d}^{-1}$ and 4.10- and 3.23- $\mathrm{mm} \mathrm{d}^{-1}$, with higher $\mathrm{ET}_{\mathrm{c}}$ values recorded in the reproductive phases of culture, flowering and grain filling.

It is interesting to note that in the early stages of development the evaporation coefficient represents the major part of the evapotranspiration of the crop, even with the irrigation interval. As the crop develops, the dynamics are reversed, so that the soil cover by the leaves of the crop substantially reduces the direct evaporation of the soil and the culture becomes more representative in the evapotranspiration.

In a study carried out in China, to determine the crop coefficient of wheat drip irrigated, were recorded $\mathrm{k}_{\mathrm{cb}}$ values of $0.25,1.06$ and 0.34 for the initial, intermediate and final phases, respectively (Gao et al., 2014). The total evapotranspiration of the crop in three years of cultivation ranged from 393 to $449 \mathrm{~mm}$.

The $\mathrm{ET}_{\mathrm{o}}$ estimated by the Penman-Monteith method (Allen et al., 1998) in the two years of cultivation was close to the region average. For the coefficients, the values of the observed crop coefficients are similar to or higher than those reported in the literature. The largest difference seems to be with respect to $k_{e}$, so the data suggest a higher value of soil water evaporation coefficient along the cycle.

Research conducted in northern China (with semi-arid climate, dry and cold winter and hot and humid summer) with wheat irrigated in the winter and corn using the dual culture $k_{c}$ method verified $k_{c b}$ and $k_{e}$ maximum close to 1.1 and 1.0 in the flowering and maturation phase in two years of cultivation (Zhao et al., 2013). During wheat cultivation, soil water evaporation represented $29 \%$ of $\mathrm{ET}_{\mathrm{c}}$. The researchers suggested that the soil water evaporation data measured in small-lysimeters should be used with caution, as there is no water withdrawal by the roots in the small-lysimeters soil, and it may occur that water evaporation is overestimated.

The soil cover provided by cultural remains can be used as a tool to minimize water loss through evaporation. Researchers evaluating the evaporation of water from the soil due to different fractions of soil cover per straw of wheat, verified that the evaporation can be reduced by up to $60 \%$ compared to the uncovered soil (Freitas et al., 2014).

According to research carried out in China, radiation is the major responsible for the variation in the daily values of $E T_{C}$ and can represent up to $88 \%$ of the $\mathrm{ET}_{\mathrm{c}}$ (Yang et al., 2014), evaluating the evapotranspiration and winter cultivation coefficient. Regarding the daily variation of the crop coefficients, the environmental factors with the greatest influence are wind speed, relative humidity, soil moisture and vapor pressure deficit. Total evapotranspiration of the crop was $252.4 \mathrm{~mm}$. In Maringá, Paraná State, researchers determined the cultivation coefficient of the wheat crop in weighing lysimeters and the coefficient of evaporation of soil water by small-lysimeters. The values determined were 0.67 , $0.67,1.01,1.03$ and 0.42 for the stages of tillering, stem elongation, panicle emission, flowering and maturation, respectively (Vieira et al. 2016). They also demonstrated the need for local studies to determine the crop coefficient in the climatic conditions of crop development. Research with dual $k_{c}$ in wheat-corn cultivation system in succession, the researchers obtained baseline crop coefficients of $0.25,1.15$ and 0.30 for the initial, developmental and final stages. At the beginning of the crop the soil water evaporation corresponded to about $80 \%$ of the $\mathrm{ET}_{\mathrm{c}}$, reducing to $5 \%$ in the following stages. The mean during the cycle was $28 \%$ for wheat (Zhang et al., 2013). Several studies have been carried out to determine the coefficient of cultivation of several species in different regions of the planet. Even the methodology of FAO's dual kc, report 56 showed good accuracy in estimating evapotranspiration and adjustment coefficients for different climatic conditions, genetic improvement and cropping systems evolved greatly, justifying the need for regional work to determine crop evapotranspiration in local conditions, since the use of a general coefficient may not represent the local conditions (Pereira et al., 2015b). In this sense, research to determine the double crop coefficient for common bean cultivated in Oxisol in Tangará da Serra, Mato Grosso State, researchers found that underestimation of $\mathrm{k}_{\mathrm{e}}$ compared to the standard method (Fenner et al., 2016). Irrigation interval and cropping system may influence the increase of soil water evaporation. The highest evaporation values are recorded when the soil is at high humidity. As it dries, evaporation decreases, and evaporation will depend on the movement of water in the soil (Philip, 1957; Ponciano et al., 2015). Analyzing the information generated and available, it is necessary to use them judiciously for planning and decision making. This information can support governmental and private actions regarding the use of water resources in agriculture and technical assistance policies to optimize agricultural production, optimizing areas for cultivation and contributing to food security (Ali and Talukder, 2008).

\section{Evapotranspiration by the water balance method}

The mean evapotranspiration of the wheat crop determined by the water balance method ranged from 3.30 to $6.43 \mathrm{~mm} \mathrm{~d}^{-1}$ (Table 3). The values determined by this method are higher than those estimated by the dual kc method and those determined by weighing lysimeters. 
Table 1. Physical-hydric characterization of Oxisol, clayey texture, of experimental area.

\begin{tabular}{|c|c|c|c|c|c|}
\hline \multirow{2}{*}{$\begin{array}{l}\text { Layer } \\
\mathrm{m}\end{array}$} & $\theta_{\mathrm{cc}}$ & $\theta_{\mathrm{PMP}}$ & $\rho$ & $\rho_{\mathrm{s}}$ & $\alpha$ \\
\hline & $\mathrm{m}^{3} \mathrm{~m}^{-3}$ & & $\mathrm{~kg} \mathrm{dm}^{-3}$ & & $\%$ \\
\hline 0.0 a 0.20 & 0.26 & 0.11 & 1.20 & 2.65 & 54.72 \\
\hline
\end{tabular}

BRS 254

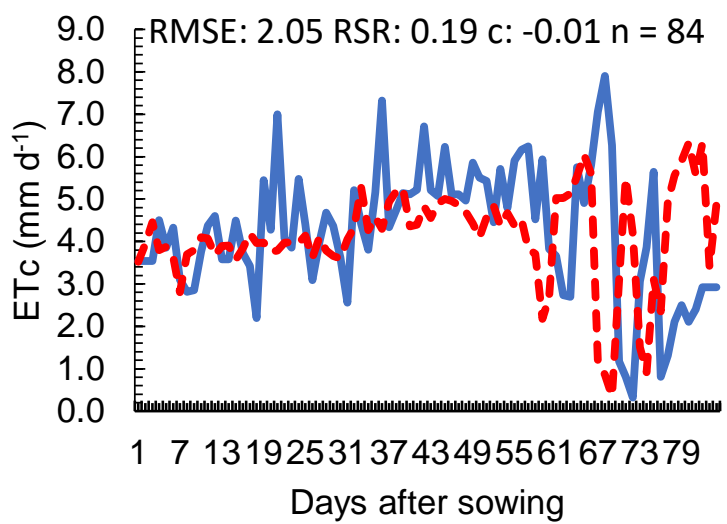

BRS 254

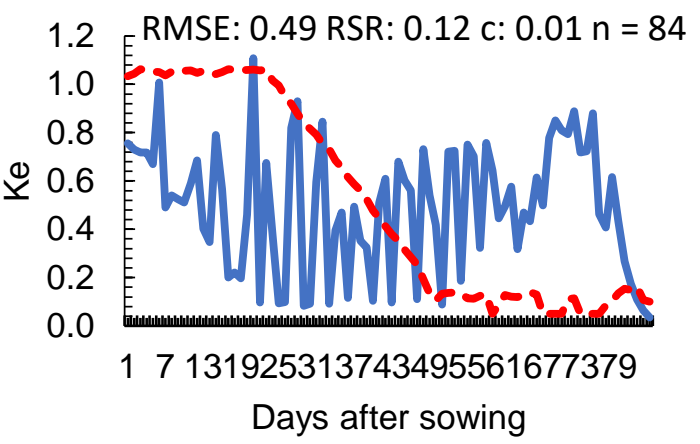

BRS 254

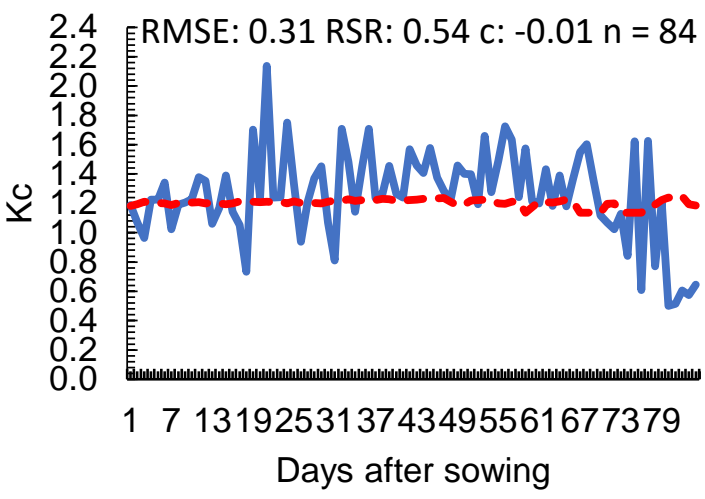

BRS 254

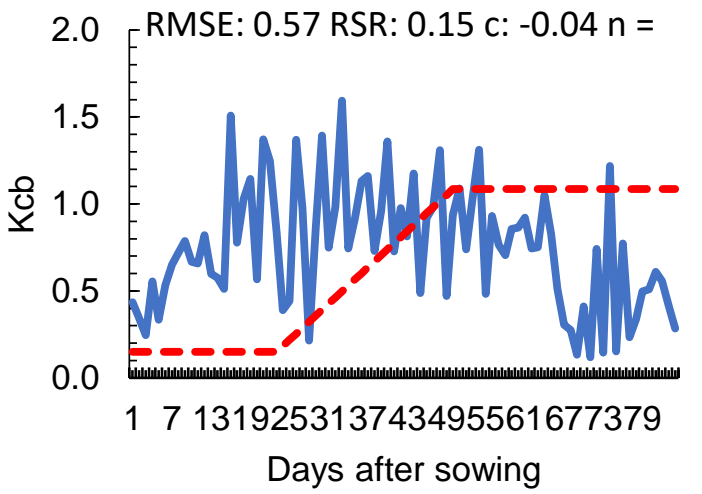

Fig 1. Evapotranspiration and wheat cultivation coefficients BRS 254, determined in lysimeter (continuous blue line) and estimated by the FAO method (dashed line drawn). Rondonópolis, Mato Grosso - Brazil, 2016.

Table 2. Crop coefficients by phenological stage for wheat cultivars BRS 254 and 394, cultivated in Oxisol. Rondonópolis, Mato Grosso - Brazil.

\begin{tabular}{|c|c|c|c|c|c|}
\hline \multirow{2}{*}{ Phenological stage } & \multicolumn{5}{|c|}{ BRS 254} \\
\hline & $\mathrm{k}_{\mathrm{cb}}$ & $\mathrm{k}_{\mathrm{e}}$ & $\mathrm{k}_{\mathrm{c}}$ & $\mathrm{ET}_{\mathrm{c}}$ & $\mathrm{ET}_{\mathrm{o}}$ \\
\hline \multicolumn{6}{|l|}{ Seeding } \\
\hline Emergency & 0.42 & 0.72 & 1.13 & 3.80 & 3.36 \\
\hline Tillering & 0.78 & 0.52 & 1.29 & 4.05 & 3.12 \\
\hline Flowering & 0.94 & 0.39 & 1.33 & 4.71 & 3.53 \\
\hline Maturation & 0.74 & 0.58 & 1.32 & 4.46 & 3.30 \\
\hline Harvest & 0.47 & 0.13 & 0.59 & 2.35 & 4.16 \\
\hline \multirow[t]{3}{*}{ Average } & 0.67 & 0.47 & 1.13 & 3.87 & 3.49 \\
\hline & \multicolumn{5}{|c|}{ BRS 394} \\
\hline & $\mathrm{k}_{\mathrm{cb}}$ & $\mathrm{ke}_{\mathrm{e}}$ & $\mathrm{k}_{\mathrm{c}}$ & $\mathrm{ET}_{\mathrm{c}}$ & $\mathrm{ET}_{0}$ \\
\hline \multicolumn{6}{|l|}{ Seeding } \\
\hline Emergency & 0.28 & 1.04 & 1.32 & 4.59 & 3.49 \\
\hline Tillering & 0.27 & 0.96 & 1.23 & 3.66 & 2.93 \\
\hline Flowering & 0.65 & 0.65 & 1.30 & 4.17 & 3.21 \\
\hline Maturation & 0.98 & 0.34 & 1.32 & 4.23 & 3.21 \\
\hline Harvest & 0.66 & 0.51 & 1.17 & 3.86 & 3.28 \\
\hline Average & 0.57 & 0.70 & 1.27 & 4.10 & 3.23 \\
\hline
\end{tabular}


BRS 394

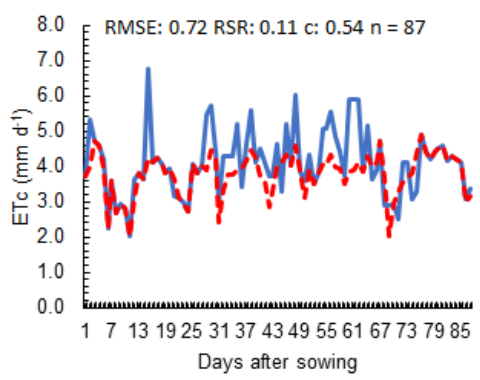

BRS 394

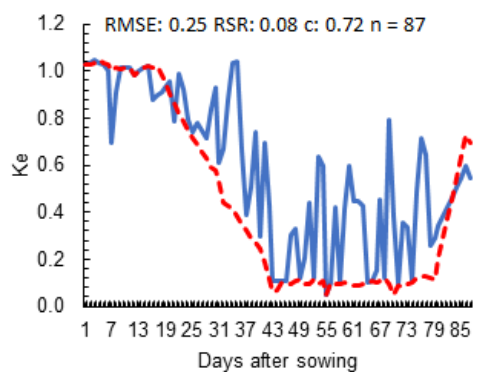

BRS 394

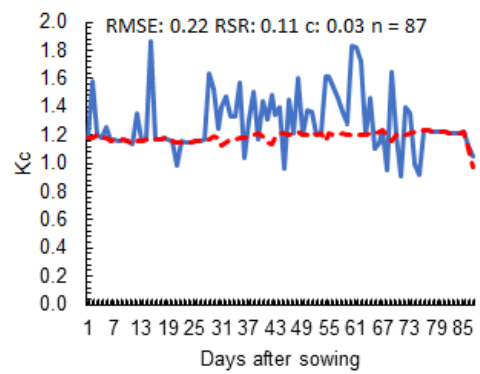

BRS 394

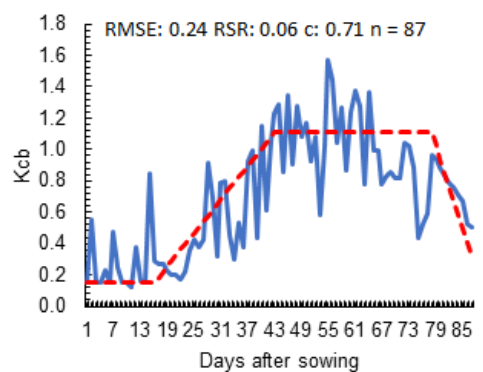

Fig 2. Evapotranspiration and wheat cultivation coefficients BRS 394, determined in lysimeter (continuous blue line) and by the FAO method (dashed line drawn). Rondonópolis, Mato Grosso - Brazil, 2017.

Table 3. Precipitation (P), irrigation (I), capillary ascension (CA), deep drainage (DD), crop evapotranspiration (ET $\mathrm{c}$ ) of irrigated wheat, cultivars BRS 254 and 394.

\begin{tabular}{|c|c|c|c|c|c|c|}
\hline \multirow{2}{*}{ Experiment } & \multirow{2}{*}{ Year } & $P$ & 1 & $A C / D D$ & $\mathrm{ET}_{\mathrm{c}}$ & $\mathrm{ET}_{\mathrm{c}}$ \\
\hline & & $\mathrm{mm}$ & & & Total & 'erage $\left(\mathrm{mm} \mathrm{d}^{-1}\right)$ \\
\hline BK & 2016 & 35.10 & 248.37 & -312.08 & 217.51 & 3.30 \\
\hline BS & 2016 & 35.10 & 241.66 & -305.20 & 381.01 & 5.80 \\
\hline$A$ & 2016 & 63.30 & 258.84 & -89.30 & 321.96 & 6.19 \\
\hline CK & 2017 & 37.90 & 404.41 & -172.66 & 418.09 & 6.43 \\
\hline $\mathrm{CS}$ & 2017 & 37.90 & 418.30 & -106.83 & 327.37 & 5.04 \\
\hline
\end{tabular}

BRS 254

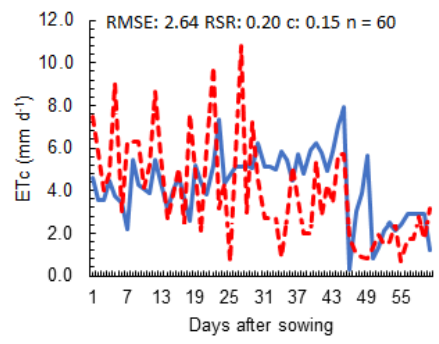

BRS 394

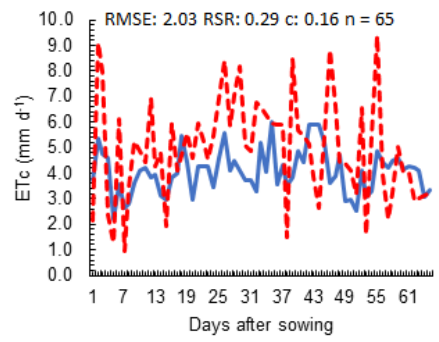

BRS 254

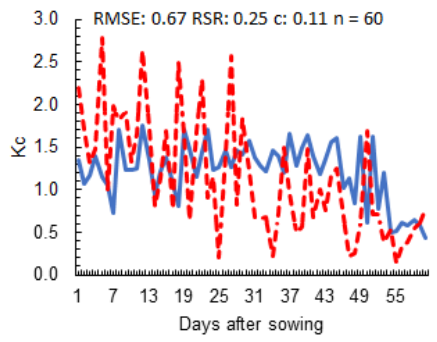

BRS 394

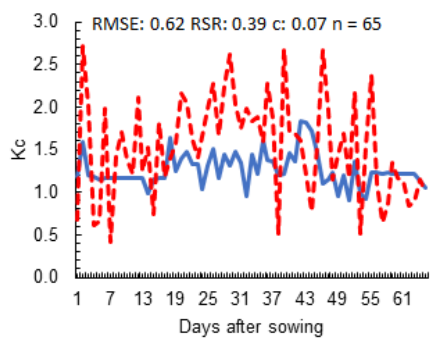

Fig 3. Evapotranspiration and wheat cultivation coefficients BRS 254 and BRS 394, determined in lysimeter (continuous blue line) and soil water balance method (dashed line drawn). Rondonópolis, Mato Grosso - Brazil. 
In general, wheat crop evapotranspiration determined by the water balance method was larger than that determined by the weighing lysimeters and estimated by the dual kc method of FAO.

The highest values of $\mathrm{ET}_{\mathrm{c}}$ can be related to the time required for the redistribution of water in the soil, especially in situations after more voluminous rains or irrigations. In this way the water balance tends to estimate extremely high values (Valmir Júnior et al., 2001).

The monitoring of soil moisture and water storage variation is fundamental to quantify the water availability for the crop and to decide on management strategies that optimize the use of financial and environmental resources. By means of this monitoring, it is possible to carry out the water balance and avoid losses of water by drainage.

When working with the evapotranspiration estimated by the water balance, it is recommended the daily monitoring of the information, since the use of weekly or monthly balances, for example, does not include the variation of the potential gradient during the evaluated interval (Libardi, 2005). Daily measurements of soil moisture and water storage also minimize the possibility of errors, since there is a greater number of data during the cycle, which facilitates the checking of outliers.

\section{Evaluation of the performance of the models}

Cultivation coefficients and evapotranspiration determined by the $\mathrm{FAO}$, lysimeter and soil water balance methods presented different behaviors (Figures 1, 2 and 3).

Higher values of RMSE for the $\mathrm{ET}_{\mathrm{c}}$ variable are verified, regardless of the method compared, FAO or water balance. Considering the confidence index ("c"), only the FAO method presented "poor" and "good" performance for the $\mathrm{ET}_{\mathrm{c}}$ and $\mathrm{k}_{\mathrm{e}}$ variables, respectively, for cultivar BRS 394, the other variables being for this method and for the balance showed poor to bad performance for both cultivars when compared to the lysimeter method.

If we consider the RMSE standardized with the standard deviation of the observed data, the RSR, there is a satisfactory performance for the methods used, so that the closer to zero the index, the better the model performance. RSR ranged from 0.06 to 0.54 for the data set evaluated.

Over the last decade, research has shown kc results similar to those proposed by FAO-56. However, there has been a trend towards increases in these values when fieldwork is carried out. Such results may lead to an underestimation of the evapotranspiration and productivity data generated by the simulation models.

In a study comparing the dual $\mathrm{k}_{\mathrm{c}}$ observed with that estimated by SIMDualKc in three years of drip irrigated wheat cultivation, researchers found values of RMSE, RSR and "d" of $0.43 \mathrm{~mm} \mathrm{~d}^{-1}$, $0.31 \mathrm{~mm} \mathrm{~d}^{-1}$ and 0.98 (Gao et al., 2014). The researchers emphasized the importance of correct determination of $E T_{c}$ for irrigation management and that its management has effects on evapotranspiration and crop productivity.

Comparing four methods to determine the evapotranspiration of the wheat crop, it was verified that the determination of soil water evaporation is better measured in small-lysimeters than estimated by the other methods, with a relative error of around 19\% (Rafi et al., 2019). The authors also found that, although the values of $k_{c}$ estimated by the FAO are acceptable, there is a tendency of overestimation of evapotranspiration and underestimation of soil water evaporation, considering the study of the components alone.

A study evaluating the water consumption of the wheat crop, in the city of Piracicaba, state of São Paulo, pointed to mean $\mathrm{ET}_{\mathrm{c}}$ values of 3.02. $\mathrm{mm} \mathrm{d}^{-1}$ with mean $\mathrm{k}_{\mathrm{c}}$ of 0.85 , in a total cycle of 115 days (Libardi and Costa, 1997). A water stress of about $50 \%$ of $\mathrm{ET}_{\mathrm{c}}$ significantly reduces biomass production and yield of wheat (Thapa et al., 2019).

The absence of trend in the estimation of $\mathrm{kc}$ by the FAO method (Figures 1 and 2) compared to the standard method (lysimeters), this an indicative that the method was not able to detect evapotranspiration changes like the standard method.

In general, the data observed in the field presented higher values than those simulated by the dual $k_{c}$ method. The evapotranspiration of the simulated culture is based on a standardized maximum $k_{c}$ value (Allen et al., 1998), so that higher values are not simulated. Thus, there is a tendency for the values of $k_{c}, k_{c b}$ and $k_{e}$ given to the field, regardless of the method used, to be larger than the standardized data. It is believed that this is one of the main conditioning factors for the low efficiency of the methods used.

However, there is evidence of crop coefficients with higher values than those standardized by FAO 56 . In a study conducted in the Federal District (Goiás State - Brazil), $\mathrm{k}_{\mathrm{c}}$ values up to $30 \%$ were higher than those reported in the literature for bean, wheat, corn and rice. The $k_{c}$ for wheat during the period of greatest demand of water by the crop was 1.57 (Guerra et al., 2003).

\section{Materials and methods}

\section{Conduction of study}

The research was carried out in the experimental area of the Institute of Agrarian and Technological Sciences - ICAT, Federal University of Mato Grosso - UFMT, Rondonópolis Campus between April and August of 2016 and 2017 respectively. The area is geographically located at latitude $16^{\circ} 27^{\prime}$, longitude $54^{\circ}$ $34^{\prime}$ with altitude of $284 \mathrm{~m}$. The climate of the region (Aw) (Köppen, 1918; Kottek et al., 2006), is characterized by two predominant seasons, dry winter (growing season) and rainy summer. The average annual rainfall is $1416.02 \mathrm{~mm}$ and average air temperature is $25.11^{\circ} \mathrm{C}$ (Souza et al., 2013).

\section{Plant materials}

Five wheat crops were planted, three in the year 2016 (cultivar BRS 254) and two in the year 2017 (cultivar BRS 394). The lysimeters were only installed in plots with nitrogen and potassium fertilization management, repeated twice in 2016, with sowing on 05/05/2016 and 06/20/2016 (Table 1). Throughout the text, the experiments will be called A (for the second sowing of 2016), BK and BS, for the first sowing of 2016 with manure management with potassium and sulfur and $\mathrm{CK}$ and CS, for sowing with fertilization management with potassium and sulfur in the year 2017.

The soil of the area is an Oxisol (EMBRAPA, 2013), clayey texture $\left(423,133\right.$ and $444 \mathrm{~g} \mathrm{~kg}^{-1}$ of sand, silt and clay, 
respectively). The results of the soil chemical analysis of the area are presented in Supplementary Table 2.

The soil physical-water characterization of the experimental area can be verified in Table 1. The meteorological data used in the two years were collected in an automatic agrometeorological station belonging to the ICAT, located approximately $150 \mathrm{~m}$ from the experimental area.

\section{Irrigation management}

In both years of cultivation, the area was irrigated by conventional spraying, composed of a self-propelled system model Hydro Roll Sector 75 and an adapted irrigation bar $30 \mathrm{~m}$ wide with 12 sprinklers spaced $2.5 \mathrm{~m}$ apart. The coefficient of uniformity of distribution of the system is $85 \%$. The water layer to be applied was determined by the sum of the evapotranspiration of the crop and the moment of irrigation indicated by the soil moisture in the layer from 0 to $0.20 \mathrm{~m}$. When the moisture in this layer, which was obtained by a moisture profiling probe (Diviner 2000), reached the value close to $0.18 \mathrm{~m}^{3} \mathrm{~m}^{-3}$, the irrigation of the experiment was performed. This value was defined considering an average evapotranspiration of $5 \mathrm{~mm} \mathrm{~d}^{-1}$ with a coefficient of depletion of 0.50 , corresponding to the group of annual crops.

\section{Experimental design}

Each experimental unit consisted of 9 rows spaced apart by $0.20 \mathrm{~m}$ with $6 \mathrm{~m}$ length. As a useful area we considered the 5 central lines and $0.5 \mathrm{~m}$ of border at each end, totaling an area of $5 \mathrm{~m}^{2}$.

Three nitrogen and potassium doses $(0-0,140-100,280-200 \mathrm{~kg}$ $\left.\mathrm{ha}^{-1}\right)$ and three nitrogen and sulfur doses $(0-0,140-50,280-100$ $\mathrm{kg} \mathrm{ha}^{-1}$ ) were used for the fertilization of the experiments. The nitrogen source used was urea divided into two applications (30\% at sowing and $70 \%$ at 15 days after sowing, corresponding to tillering). Fertilization with phosphorus $\left(\mathrm{P}_{2} \mathrm{O}_{5}\right)$ (200 kg ha-1) and potassium $\left(\mathrm{K}_{2} \mathrm{O}\right)$ had as their source the simple superphosphate and potassium chloride respectively. The sulfur was supplied via elemental sulfur $\left(\mathrm{S}^{\circ}\right)$. For fertilization with micronutrients, $50 \mathrm{~kg}^{-1}$ of FTE-BR12 (9\% $\mathrm{Zn} ; 1,8 \% \mathrm{~B} ; 0,8 \% \mathrm{Cu} ; 2 \% \mathrm{Mn} ; 3,5 \% \mathrm{Fe} ; 0,1 \% \mathrm{Mo})$.

350 viable seeds per $\mathrm{m}^{2}$ were sown, with the aid of a specific sowing machine for experimental plots, model SEMINA II (Sattler et al., 2005).

The base fertilization was applied with the sowing machine at approximately $5 \mathrm{~cm}$ depth, the same depth of seed distribution and the manure application was performed manually.

\section{Reference evapotranspiration by the Penman-Monteith method and estimation of the dual $k_{c}$}

By means of the data collected in the meteorological station it was estimated the reference Evapotranspiration (ETo) by the Penman-Monteith method, FAO standard (Allen et al., 1998). For the simulation of wheat crop evapotranspiration in two years considering the treatments studied, the dual $k_{c}$ methodology was used (Allen et al., 1998), described in the FAO- 56 bulletin. The values of $k_{c}, k_{c b}$ and $k_{e}$ tabulated by FAO (Bulletin 56) (Allen et al., 1998) were considered as standard values and used for comparative and evaluative effect of the coefficients determined by other methods.

The baseline $\mathrm{k}_{\mathrm{cb}}$ coefficients used are: $0.15,1.10$ and 0.23 for the initial, development and final phases, respectively. The values of $k_{c b}$ and $k_{e}$ were estimated daily in the five experiments. Equation 1 describes the procedure for obtaining $k_{c b}$.

$\mathrm{k}_{\mathrm{cb}}=\mathrm{k}_{\mathrm{cb}(\text { tabulated) }}+\left[0,04\left(\mathrm{u}_{2}-2\right)-0,004\left(\mathrm{UR}_{\text {minimum }}-45\right)\right]\left(\frac{\mathrm{h}}{3}\right)^{0,3}$

(1)

em que:

$k_{c b}$ (tabulated) - the value for $k_{c}$ development or final (if $\geq 0.45$ ); $\mathrm{u} 2$ - average daily wind speed at $2 \mathrm{~m}$ height during the development or final phase $\left(\mathrm{m} \mathrm{s}^{-1}\right)$ for $1 \mathrm{~m} \mathrm{~s}^{-1} \leq \mathrm{u} 2 \geq 6 \mathrm{~m} \mathrm{~s}^{-1}$; and, URminimum - minimum daily average relative humidity during the development or final phase (\%) to $20 \% \leq$ URmin $\geq$ $80 \% ; \mathrm{h}$ - the height of the average plant during the development or final phase $(\mathrm{m})$ to $20 \% \leq U R \min \geq 80 \%$.

The $k_{e}$ was obtained according to equation 2 :

$k_{e}=k_{r}\left(\right.$ kcmaximum $\left.-k_{c b}\right) \leq F_{e w}$ kcmaximum

(2)

on what:

$k_{e}$ - coefficient of evaporation of soil water; $k_{c b}$ - basal coefficient of culture; $k_{c}$ maximum - maximum value of $k_{c}$ after rain or irrigation; $k_{r}$ - coefficient of reduction of soil water evaporation; e, $\mathrm{F}_{\mathrm{ew}}$ - soil fraction exposed and moistened.

Determination of evapotranspiration and evaporation by lysimeters and small-lysimeters filled with soil monoliths

Twelve lysimeters and small-lysimeters were filled by soil monoliths, preserving the soil structure at conditions very similar to those observed in the field (Aboukhaled et al., 1982; Flumignan et al., 2012) (Supplementary Figure 1).

The soil monoliths were removed in the same size as the lysimeters. The equipment used and the collection procedures followed the technical recommendations of the equipment, a mechanical sampler for collecting monoliths and soil columns with preserved structure (Venzon et al., 2018).

The lysimeters were installed in the central line of each plot, being careful to preserve the condition of the plot and generate the least disturbance possible. Each set was accompanied by an external wall to prevent entry of soil into the system and compromise daily measurements (Flumignan et al., 2012). The installed set (lysimeter + small-lysimeters + access tube) can be observed in Supplementary Figure 2.

Wheat crop evapotranspiration was obtained daily by mass variation of lysimeters, described in equation 3 :

$\mathrm{ETc}=\frac{\Delta \mathrm{ML}}{\mathrm{AL}}+\mathrm{I}+\mathrm{P}$

(3)

on what:

$\mathrm{ET}_{\mathrm{c}}$ - crop evapotranspiration $\left(\mathrm{mm} \mathrm{d}^{-1}\right) ; \Delta \mathrm{ML}$ - mass variation of the set $\left(\mathrm{kg} \mathrm{d}^{-1}\right) ; A L$ - lysimeter area $\left(0.0674 \mathrm{~m}^{2}\right) ; \mathrm{I}$ - irrigation $\left(\mathrm{mm} \mathrm{d}^{-1}\right)$; and, $\mathrm{P}$ - precipitation $\left(\mathrm{mm} \mathrm{d}^{-1}\right)$.

The soil water evaporation coefficient $\left(k_{e}\right)$ was obtained by the ratio between the mass variation of the small-lysimeters and 
the $\mathrm{ET}_{0}$, Penman-Monteith method (Allen et al., 1998; Flumignan et al., 2012), equation 4.

$k_{e}=\frac{\mathrm{E}_{\mathrm{ML}}}{\mathrm{ETO}}$

(4)

on what:

$k_{e}$ - coefficient of evaporation of soil water; $E_{M L}$ : evaporation of small-lysimeters $\left(\mathrm{mm} \mathrm{d}^{-1}\right)$; and, $\mathrm{ET}_{\mathrm{o}}$ - reference evapotranspiration Penman-Monteith method $\left(\mathrm{mm} \mathrm{d}^{-1}\right)$.

Finally, the basal crop coefficient $\left(\mathrm{k}_{\mathrm{cb}}\right)$ of wheat, obtained by equation 5 :

$K_{c b}=\frac{E T_{c}}{E T_{o}}-K_{e}$

(5)

on what:

$\mathrm{k}_{\mathrm{cb}}$ - basal crop coefficient (dimensionless); $\mathrm{ET}_{\mathrm{c}}$ - crop evapotranspiration $\left(\mathrm{mm} \mathrm{d}^{-1}\right) ; k_{e}$ - coefficient of soil water evaporation (dimensionless); and, $\mathrm{ET}_{\mathrm{O}}$ - reference evapotranspiration $\left(\mathrm{mm} \mathrm{d}^{-1}\right)$.

The results were organized by stages of development of the wheat crop and by the general average during the growing cycle in both years.

\section{Evapotranspiration by soil water balance method}

The lysimetric sets were accompanied by an access tube for measuring the volumetric content of water in the soil, determined by a Diviner ${ }^{\circledR} 2000$ Sentek capacitance probe. The measurements were performed in intervals of $0.10 \mathrm{~m}$ to the depth of $0.50 \mathrm{~m}$. The readings were performed daily between 7 and $8 \mathrm{~h}$, at the same time as the weighing of the lysimetric sets.

The data obtained by the probe were used to determine the irrigation moment (when the volumetric content of water in the soil in the 0 to $0,20 \mathrm{~m}$ layer reached $0.18 \mathrm{~m}^{3} \mathrm{~m}^{-3}$ ) and the calculation of the water storage in the soil up to the depth of $0.5 \mathrm{~m}$ and determination of the matric potential of each layer, through the soil water retention characteristic curve (Libardi, 2005).

The relationship between the hydraulic conductivity of the soil and the soil volumetric content was determined by the instantaneous profile method (Watson, 1966; Hillel et al., 1972; Libardi et al., 1980).

Equation 6 describes the function $\mathrm{K}(\theta)$.

$K(\theta)=K o * e^{\gamma\left(\theta-\theta_{0}\right)}$

(6)

on what:

$\mathrm{K}(\theta)$ - hydraulic conductivity as a function of the volumetric soil water content $\left(\mathrm{mm} \mathrm{d}^{-1}\right) ; \mathrm{K}_{0}$ - hydraulic conductivity in saturated soil $\left(\mathrm{mm} \mathrm{d}^{-1}\right) ; \gamma$ - angular coefficient of the regression between the hydraulic conductivity as a function of the volumetric content of water in the soil; $\theta$ - current volumetric content $\left(\mathrm{m}^{3}\right.$ $\left.\mathrm{m}^{-3}\right)$; and, $\theta_{0}$ - volumetric soil water content in saturated soil $\left(\mathrm{m}^{3} \mathrm{~m}^{-3}\right)$.

Internal drainage and capillary rise were estimated by the Darcy-Buckingham equation (equation 7), which describes the movement of water in unsaturated soil (Libardi, 2005). The limit of $0.40 \mathrm{~m}$ was determined by observing the data generated by the moisture profile with data collected by the Diviner 2000 probe.

$q_{0,4 m}=-K(\theta)\left[\frac{\phi_{t(0,3 m)}-\phi_{t(0,5 m)}}{0,2}\right]$

(7)

on what:

$K(\theta)$ - hydraulic conductivity function as a function of the volumetric content of water in the soil at depth of $0.4 \mathrm{~m} ; \phi_{t^{-}}$ total potential gradient in the layers of 0.3 and $0.5 \mathrm{~m}$; and, 0.2 - is the thickness in meters between the layers

Finally, the evapotranspiration of the crop was obtained by equation 8:

$E T_{c}=I+P-R O-D P+A C \pm \Delta F S H \pm \triangle A R M$

(8)

on what:

$\mathrm{ET}_{\mathrm{c}}$ - crop evapotranspiration $\left(\mathrm{mm} \mathrm{d}^{-1}\right) ; \mathrm{I}$ - irrigation (mm); P precipitation $(\mathrm{mm})$; RO - surface runoff; DP - deep drainage; AC - capillary ascension; $\triangle \mathrm{FSH}$ - horizontal subsurface flow; and, $\triangle \mathrm{ARM}$ - variation of soil water storage $\left(\mathrm{mm} \mathrm{d}^{-1}\right)$.

The surface flow and the horizontal movement in subsurface were disregarded due to the flat relief of the area (Libardi, 2005; Ghiberto et al., 2011; Libardi et al., 2015). The vertical ascending and draining movements were determined by the potential gradient above $(0.3 \mathrm{~m})$ and below $(0.5 \mathrm{~m})$ of the control layer and the amount drained or ascended obtained by equation 7.

\section{Analysis of method performance}

The quality of fit of the models tested was estimated by means of coefficients obtained from the comparison between the observed and estimated data $O i$ and $P i(i=1,2, \ldots, n)$, as well as their means $\bar{O}$ e $\bar{P}$, respectively (Legates and McCabe, 1999; Tedeschi, 2006; Moriasi et al., 2007; Pereira et al., 2015a; Wang et al., 2012).

The equations and the adjustments generated by the instantaneous profile method were tested by means of linear and non-linear regression using software R ( $R$ Core Team, 2019), using the packages "trendline" e "nlsfit".

The indices used to compare the methods were RMSE, RSR, Willmott's concordance index (d) and performance index (c). The indices generated for each model were classified according to classification criteria proposed by Camargo and Sentelhas (1997), Supplementary Table 3.

\section{Conclusion}

The average evapotranspiration of the wheat crop determined in weighing lysimeters is $3.87 \mathrm{~mm} \mathrm{~d}^{-1}$ for cultivar BRS 254- and $4.10-\mathrm{mm} \mathrm{d}^{-1}$ for cultivar BRS 394, cultivated in an irrigated system in Oxisol. The mean total $\mathrm{ET}_{\mathrm{c}}$ determined in weighing lysimeters is $360 \mathrm{~mm}$.

The methods tested, FAO and soil water balance, do not present gains in the estimation of wheat crop evapotranspiration when compared to the standard method considered, weighing lysimeters, considering the "c" performance index. The methods present low values of RMSE 
and RSR, in the estimation of basal and irrigated wheat cultivars, with values between 0.22 to 2.64 and 0.06 to 0.54 for RMSE and RSR, respectively. Considering the confidence index, none of the models tested is satisfactory for the determination of the evapotranspiration and of the basal and crop coefficients of the wheat crop. However, the FAO method presented lower mean values of RMSE and RSR compared to the soil water balance method.

\section{Acknowledgements}

The authors express their gratitude to the following organizations for collaborating in the accomplishment of this study: CAPES (Coordination for Improvement of Higher Education Personnel), CNPq (National Council for Scientific and Technological Development), and FAPEMAT (Research Support Foundation of the State of Mato Grosso).

\section{References}

Aboukhaled A, Alfaro A, Smith M (1982) Lysimeters. ed. Rome: FAO - Food and Agriculture Organization of the United Nations

Ali MH, Talukder MSU (2008) Increasing water productivity in crop production-A synthesis. Agric Water Manag. 95(1): 1201-1213.

Allen RG, Pereira LS, Raes D, Smith M (1998) Crop evapotranspiration - Guidelines for computing crop water requirements. FAO Irriga ed. Rome: FAO - Food and Agriculture Organization of the United Nations.

Allen RG, Pereira LS, Smith M, Raes D, Wright JL (2005) FAO-56 Dual crop coefficient method for estimating evaporation from soil and application extensions. J Irrig Drain Eng. 13(1): 2-13.

Allen RG, Pereira LS, Howell TA, Jensen ME (2011) Evapotranspiration information reporting: I. Factors governing measurement accuracy. Agric Water Manag. 98: 899-920. a.

Allen RG, Pereira LS, Howell TA, Jensen ME (2011) Evapotranspiration information reporting: II . Recommended documentation. Agric Water Manag. 98: 921-929. b.

Doorenbos J, Kassam AH (1979) Yield response to water. FAO Irriga ed. Rome: FAO - Food and Agriculture Organization of the United Nations.

EMBRAPA (2013) Sistema brasileiro de classificação de solos. 3. ed. Brasília - DF: EMBRAPA.

Er-Raki S, Chehbouni GB, Williams DG (2010) Using the dual approach of FAO-56 for partitioning ET into soil and plant components for olive orchards in a semi-arid region. Agric Water Manag. 97: 1769-1778.

Fenner W, Dallacort R, Freitas PSL, Faria Junior CA, Carvalho MAC, Bariviera G (2016) Dual crop coefficient of common bean in Tangará da Serra, Mato Grosso. Rev Bras Eng Agric Amb. 20: 455-460.

Flumignan DL, Faria RT, Lena BP (2012) Test of a microlysimeter for measurement of soil evaporation. Eng Agríc. 32: 80-90.

Freitas PSL, Gava R, Faria RT, Rezende R, Vieira PVD (2014) Soil evaporation under different straw mulch fractions. Afr J Agric Res. 9: 1793-1800.
Gao Y, Yang L, Shen X, Li X, Sun J, Duan A, Wu L (2014) Winter wheat with subsurface drip irrigation (SDI): Crop coefficients, water-use estimates, and effects of SDI on grain yield and water use efficiency. Agric Water Manag. 146: 1-10.

Geerts S, Raes D (2009) Deficit irrigation as an on-farm strategy to maximize crop water productivity in dry areas. Agric Water Manag. 96: 1275-1284.

Ghiberto PJ, Libardi PL, Brito AS, Trivelin PCO (2011) Components of the water balance in soil with sugarcane crops. Agric Water Manag. 102: 1-7.

Guerra AF, Rodrigues GC, Rocha OC, Evangelista W (2003) Necessidade hídrica no cultivo de feijão, trigo, milho e arroz sob irrigação no bioma Cerrado, Planaltina: Embrapa Cerrados.15 p. (Boletim de pesquisa e desenvolvimento, 100).

Hillel D, Krentos VD, Stylianou Y (1972) Procedure and test of an internal drainage method for measuring soil hydraulic characteristic in situ. Soil Sci. 114: 395-400.

Köppen W (1918) Klassifikation der klimate nach temperatur, niederschlag und jahresablauf. Petermanns Geogr Mitt. 1918

Kottek M, Greiser J, Beck C, Rudolf B, Rubel F (2006) World map of the Köppen-Geiger climate classification updated. Meteorol Z. 15(3): 259-263.

Large EC (1954) Growth stage in cereals: illustration of the Feekes scale. Plant Pathol. 3: 128-129.

Legates DR, Mccabe GJ (1999) Evaluating the use of "goodness-of-fit" measures in hydrologic and hydroclimatic model validation. Water Resour Res. 35(1): 233-241.

Libardi PL, Reichardt K, Nielsen DR, Biggar JW (1980) Simple field methods for estimating soil hydraulic conductivity. Soil Sci Soc Am J. 44(1): 3-7.

Libardi PL (2005) Dinâmica da água no solo. 1. ed. Piracicaba, SP: Edusp.

Libardi PL, Mota JCA, Assis Júnior RN, Brito AS, Amaro Filho J (2015) Water balance components in covered and uncovered soil growing irrigated muskmelon. Rev Bras Ciênc Solo. 39(5): 1322-1334.

Libardi VCM, Costa MB (1997) Consumo d'água da cultura do trigo (Triticum aestivum). Rev FZVA. 4(1): 16-23.

López-Urrea R, Montoro A, González-Piqueras L, Fópez-Fuster $P$, Fereres $E$ (2009) Water use of spring wheat to raise water productivity. Agric Water Manag. 96(9): 1305-1310.

Moriasi DN, Arnold JG, Van Liew MW, Bingner RL, Harmel RD, Veith TI (2007) Model evaluation guidelines for systematic quantification of accuracy in watershed simulations. Am Soc Agric Biol Eng. 50(3): 885-900.

Paredes P, Rodrigues GC, Alves I, Pereira LS (2014) Partitioning evapotranspiration, yield prediction and economic returns of maize under various irrigation management strategies. Agric Water Manag. 135: 27-39.

Pereira LS, Paredes P, Rodrigues GC, Neves M (2015) Modeling malt barley water use and evapotranspiration partitioning in two contrasting rainfall years. Assessing AquaCrop and SIMDualKc models. Agric Water Manag. 159: 239-254. a.

Pereira LS, Allen RG, Smith M, Raes D (2015) Crop evapotranspiration estimation with FAO56: Past and future. Agric Water Manag. 47: 4-20. b.

Philip JR (1957) Evaporation, and moisture and heat fields in the soil. J Meteorol. 14(1): 354-366. 
Ponciano IM, Miranda JH, Santos MA, Van Lier QJ, Grah VF (2015) An empirical model for predicting soil daily evaporations: soil and atmospheric variables. Rev Bras Agric Irrig. 9(4): 225-231.

Rafi ZMO, Le Dantec V, Khabba S, Mordelet P, Er-Raki S, Amazirh A, Oliveira-Guerra L, Hssaine BA, Simonneaux V, Ezzahar J, Ferrer $F$ (2019) Partitioning evapotranspiration of a drip-irrigated wheat crop: Intercomparing eddy covariance-, sap flow-, lysimeter- and FAO-based methods. Agric Forest Meteorol. 265: 310-326.

R Core Team (2019) R: A language and environment for statistical computing. R Foundation for Statistical Computing, Vienna, Austria. https://www.R-project.org/.

Sattler A, Faganello A, Portela A (2005) Semeadoras para plantio direto de parcelas experimentais. 1. ed. Rio Grande do Sul: EMBRAPA.

Silva TJA, Machado CC, Bonfim-Silva EM, Coelho RD (2005) Irrigation management on net-melon fruits cultivated under greenhouse. Eng Agríc. 25(3): 722-731.

Silva VPR, Garcêz SLA, Silva BB, Albuquerque MF, Almeida RSR (2015) Métodos de estimativa da evapotranspiração da cultura da cana-de-açúcar em condições de sequeiro. Rev Bras Eng Agríc Amb. 19(5): 411-417.

Souza AP, Mota LL, Zamadei T, Martin CC, Almeida FT, Paulino J (2013) Classificação climática e balanço hídrico climatológico no estado de Mato Grosso. Nativa. 1(1): 34-43.

Tedeschi LO (2006) Assessment of the adequacy of mathematical models. Agric Syst. 89(2-3): 225-247.

Thapa S, Xue Q, Jessup KE, Rudd JC, Liu S, Marek TH, Devkota RN, Baker JA, Baker S (2019) Yield determination in winter wheat under different water regimes. Field Crops Res. 233: 80-87.

Valmir Júnior M, Costa RNT, Aguiar JV (2001) Análise de componentes do balanço hídrico em cultura de caupi (Vigna unguiculata (L) Walp), sob condições de recarga hídrica natural. Irriga. 6(3): 91-103.

Venzon M, Bassini RT, Silva TJA, Bonfim-Silva EM (2018) Coletor de amostras de monólitos de solos de volumes variados. BR pat. 202015019059-5 U2, 03 jul. 2018.
Vieira PVD, Freitas PSL, Silva BR, Hashiguti T, Rezende R, Faria Junior CA (2016) Determination of wheat crop coefficient (Kc) and soil water evaporation (Ke) in Maringa, PR, Brazil. Afr J Agric Res. 11(44): 4551-4558.

Wang J, Zhang Y, Gong S, Xu D, Juan S, Zhao Y (2017) Evapotranspiration, crop coefficient and yield for dripirrigated winter wheat with straw mulching in North China Plain. Field Crops Res. 217: 218-228.

Wang X, Williams JR, Gassman PW, Baffaut C, Izaurralde RC, Jeong J, Kiniry JR (2012) Epic and Apex: model use, calibration, and validation. ASABE Am Soc Agric Biol Eng. 55(1996): 1447-1462.

Watson KK (1966) An instantaneous profile method for determining the hydraulic conductivity of unsaturated porous materials. Water Resour Res. 2(4): 709-715.

Yang F, Zhang Q, Wang R, Zhou J (2014) Evapotranspiration measurement and crop coefficient estimation over a spring wheat farmland ecosystem in the Loess Plateau. PLoS ONE. 9(6): 1-8.

Zadocks JC, Chang TT, Konzak CF (1974) A decimal code for the growth stages of cereals. Weed Res. 14: 415-421.

Zhang B, Liu Y, Xu D, Zhao N, Lei B, Rosa RD, Paredes P, Paço TA, Pereira LS (2013) The dual crop coefficient approach to estimate and partitioning evapotranspiration of the winter wheat-summer maize crop sequence in North China Plain. Irrig Sci. 31(6): 1303-1316.

Zhao N, Liu Y, Cai J, Paredes P, Rosa RD, Pereira LS (2013) Dual crop coefficient modelling applied to the winter wheatsummer maize crop sequence in North China Plain: Basal crop coefficients and soil evaporation component. Agric Water Manag. 117: 93-105. 